\section{Effects of Polypropylene Groundcover on Soil Nutrient Availability, Sweet Cherry Nutrition, and Cash Costs and Returns}

\author{
Xinhua Yin ${ }^{1}$, Clark F. Seavert, Janet Turner, Roberto Núñez-Elisea, \\ and Helen Cahn \\ Mid-Columbia Agricultural Research and Extension Center, Oregon State \\ University, 3005 Experiment Station Drive, Hood River, OR $97031-9512$
}

Additional index words. polypropylene groundcover, soil nutrient availability, leaf nutrition, fruit nutrition, cash costs, returns, Prunus avium

\begin{abstract}
The impacts of synthetic polypropylene groundcover in the row area of young sweet cherry (Prunus avium L.) trees (Regina on Gisela 6) on soil nutrient availability, tree mineral nutrition and productivity, and cash costs and returns were investigated on a Van Horn fine sandy loam soil at Hood River, Ore., from 2001 to 2005. Treatments included 2.44-m wide synthetic fabric groundcover made of black, woven polypropylene over the row area of cherry trees and no groundcover but with herbicide applications in the row area with the same width as the polypropylene groundcover. Soil-available $\mathrm{NO}_{3}{ }^{-}$, $\mathrm{P}, \mathrm{K}, \mathrm{Ca}, \mathrm{Mg}, \mathrm{S}, \mathrm{B}, \mathrm{Zn}, \mathrm{Mn}$, and $\mathrm{Cu}$ contents in 0 to $30 \mathrm{~cm}$ in August did not differ significantly between the cover and no cover treatments in any year except 2005, when soil $\mathbf{N}$ and $\mathrm{K}$ levels were lower with polypropylene cover. Leaf $\mathbf{N}$ concentration in August was enhanced by $11 \%$ to $19 \%$ each year in the polypropylene cover treatment. However, leaf $P$ concentration was lowered by $19 \%$ to $37 \%$ with polypropylene cover each year; and leaf $\mathrm{Ca}$ and $\mathrm{Mg}$ concentrations were reduced by $9 \%$ to $13 \%$ and $6 \%$ to $24 \%$, respectively, as a result of polypropylene cover in 3 of 5 years. Reduced leaf $P$, Ca, and Mg concentrations in the cover treatment were attributed to the diluting effects of enhanced tree growth and fruit yield. Cumulative cash costs for the orchard within the first 4 years before fruit production were $\$ 5246 /$ ha higher with polypropylene cover relative to no cover. However, these costs were offset quickly by increased returns from enhanced fruit yields. In the long-term, more fertilizers may need to be applied on polypropylene groundcovered trees to compensate for the enhanced tree growth and fruit production.
\end{abstract}

Ground management is a key orchard production practice for profitable and sustainable tree fruit production (Derr, 2001; Geldart, 1994). Effective ground management can control weeds, conserve soil moisture, prevent soil erosion, improve water infiltration and nutrient retention, enhance fruit quality, and maintain or improve soil organic matter and structure (Johnson and Samuelson, 1990; Merwin et al., 1996; Stevenson and Neilsen, 1990). Currently, herbicide application in tree rows with grass alleys between tree rows is the standard orchard ground management practice in the United States (Shribbs and Skroch, 1986). This system aims to provide a vegetation-free zone within the tree rows to minimize weed competition with trees for water and nutrients while maintaining soil structure in the alley (Parker and Hull, 1993). Although in-row herbicide application in orchards is effective in weed control, it is costly and has adversely affected soil ecosystems and the environ-

Received for publication 11 May 2006. Accepted for publication 21 Aug. 2006.

${ }^{1}$ To whom reprint requests should be addressed; e-mail xinhua.yin@oregonstate.edu. ment. For example, herbicide application in the row area of orchards has reduced soil microbial activities (Elmore et al., 1997; Glover et al., 1999) and elevated herbicide contamination of underground and surface water (Merwin et al., 1996). Therefore, there is a need to replace the traditional in-row ground management method with more sustainable and profitable practices.

Using synthetic fabric, compost, and straw to cover the row area beneath orchard trees is emerging as in-row ground management alternatives to the traditional practice of herbicide applications. Mäge (1982) has demonstrated that polypropylene groundcover could not only control weeds, but also reduce soil water evaporation. Reduced soil water evaporation generally increased soil moisture (Mäge, 1982); under some circumstances, soil aeration may be reduced because of increased soil moisture content and the existence of a physical barrier provided by the polypropylene cover on the soil surface. All these factors could have significant bearings on nutrient availability in soil and nutrient uptake by tree roots. A 6-year study on apple trees in western Canada (Neilsen et al., 2003) reported that the responses of leaf nutrient concentrations to polypropylene groundcover were nutrient-specific and varied with growing season; tree vigor and yield were higher with polypropylene groundcover relative to no cover maintained by herbicide application. Overall, the effects of synthetic polypropylene groundcover on soil nutrient availability, mineral nutrition and productivity of orchard trees, and cash costs and returns are largely unknown in Pacific Northwest tree fruit production systems. The objectives of this study were to (1) examine the effects of synthetic polypropylene groundcover in the tree row area on soil nutrient availability, leaf and fruit nutrition of young sweet cherry, and cash costs and returns; and (2) evaluate the impacts of synthetic polypropylene groundcover in the row area on soil moisture and temperature and the growth, yield, and quality of young sweet cherry. This publication reports the results relevant to the first objective.

\section{Materials and Methods}

Site description and experimental design. As part of an ongoing research project on the use of synthetic polypropylene groundcover for sweet cherry (Núñez-Elisea et al., 2004, 2005a, 2005b), this study was conducted on a Van Horn fine sandy loam soil at the MidColumbia Agricultural Research and Extension Center, Hood River, Ore., from 2001 through 2005. The Van Horn series consists of well-drained soils on uplands. These soils formed in stratified alluvial deposits, and they are moderately permeable. The 1.2-ha orchard used in this study was planted at $5.4 \mathrm{~m}$ between rows and $3 \mathrm{~m}$ within rows in March 2001 with second-leaf Regina sweet cherry on Gisela 6 rootstock. The trees were trained to a central leader.

A randomized complete block design was used with two treatments and eight replicates in this study. One treatment was $2.44-\mathrm{m}$ wide synthetic fabric made of black woven polypropylene (DeWitt Co., Sikeston, Mo.) covering the tree row centers. This waterpermeable polypropylene was placed on the ground in April 2001 with 30-cm wide edges buried in the soil on both sides of a tree row. The other treatment was the control (no groundcover but with herbicide applications in the row area of same width to control weeds). Roundup (glyphosate) at 1388 $\mathrm{mL} \cdot \mathrm{ha}^{-1}$ mixed with $147 \mathrm{~L} \cdot \mathrm{ha}^{-1}$ of water was sprayed in the control treatment in early June each year from 2001 to 2005. Each plot had 36 trees (including four pollinizers) in four consecutive rows. Only the middle 12 trees in the two central rows were used for data collection, including tree growth and fruit yield measurements. Fertilizer recommendations were based on shoot growth and nutrient concentrations in leaf and soil in this study. No N, P, or K fertilizer was applied to either treatment during the first 3 years of the study. However, $\mathrm{N}$ fertilizer was applied to both treatments in April at $8 \mathrm{~kg} \mathrm{~N} \cdot \mathrm{ha}^{-1}$ in 2004 and $33 \mathrm{~kg} \mathrm{~N} \cdot \mathrm{ha}^{-1}$ in 2005 as ammonium sulfate. Irrigation scheduling was conducted separately for each individual plot on a weekly 
basis from May to September according to tree needs in relation to soil moisture. Soil moisture content was measured weekly and irrigation was conducted during the irrigation season from May to September with a portable frequency domain reflectometry probe (Diviner 2000; Sentek, Stepney, Australia) from 2001 to 2004 and using a neutron probe (model CPN 503) in 2005.

Soil and plant sampling and analysis. Soil sampling was conducted at the depth interval of 0 to $30 \mathrm{~cm}$ for each plot in October 2000 before tree planting and treatment imposition and in August of 2001, 2002, 2003, 2004, and 2005, approximately one month after fruit harvest. Ten soil cores per sample were randomly collected from each plot with a $2.5-\mathrm{cm}$ diameter soil probe after removing visible tree and weed residues from the soil surface. Each year, a composite sample was collected between four trees $(3 \mathrm{~m}$ apart) in the middle of each plot. Each sample was placed in a soil-sampling bag and then stored in a cold storage room at $1{ }^{\circ} \mathrm{C}$. All samples were air-dried, ground to pass through a 2-mm sieve, and thoroughly mixed. Soil nitrate, available $\mathrm{P}, \mathrm{K}, \mathrm{Ca}, \mathrm{Mg}, \mathrm{S}, \mathrm{B}, \mathrm{Zn}$, $\mathrm{Mn}$, and $\mathrm{Cu}$ contents were extracted using the Mehlich III method (Mehlich, 1984). Soil pH was determined in a 1:1 (soil: $\left.\mathrm{H}_{2} \mathrm{O}\right)$ solution (Watson and Brown, 1998), and organic matter was measured using the loss-on-ignition method (Combs and Nathan, 1998).

A leaf sample was taken randomly from each plot in August of 2001, 2002, 2003, 2004 , and 2005, respectively. Each year, the sample was collected from the same four trees and under similar weather conditions. Each leaf sample contained 24 newly but fully developed midterminal leaves from current year shoots at $1.5-\mathrm{m}$ level in the tree canopy. A fruit sample was collected from each plot at harvest on 11 July 2005. Each sample contained 24 mature fruits that were randomly sampled from the central 12 data trees (two fruits per tree) in each plot. All these leaf and fruit samples were cleaned, oven-dried at $65{ }^{\circ} \mathrm{C}$, and ground to pass through a $1-\mathrm{mm}$ sieve. Total $\mathrm{N}$ was determined using a combustion method with a Carlo Erba 1500 series Nitrogen/Carbon Analyzer (Gavlak et al., 1994). Total P, K, $\mathrm{Ca}, \mathrm{Mg}, \mathrm{S}, \mathrm{B}, \mathrm{Zn}, \mathrm{Mn}$, and $\mathrm{Cu}$ were digested in a CEM MDS 2100 series microwave (CEM Corp., Matthews, N.C.) using nitric acid and hydrogen peroxide and the digest was analyzed on a Thermo Jarrell Ash 1100 ICP (Thermo and Fisher Scientific, Waltham, Mass.) (Gavlak et al., 1994).

Cash costs and returns. Cash costs for each orchard establishment and management activity, including land preparation (ripping, disking, root removal, and fumigation), tree planting, purchasing and installation of polypropylene groundcover, tree pruning, control of weeds, diseases, and insects, irrigation, fertilization, and fruit harvesting, were recorded each year from 2000 through 2005 for the calculation of annual and cumulative cash costs. Accumulated interest on previous expenses was calculated at a $10 \%$ annual interest rate.
Gross economic returns from fruit sales were calculated based on fruit yield and fruit price $(\$ 2.20 / \mathrm{kg})$ for both 2004 and 2005 .

Statistical analysis. Analysis of variance (ANOVA) for each variable was conducted separately each year because of the inhomogeneous errors across years using the ANOVA procedure in the SAS package (SAS Institute, 2002). Analysis of variance was performed on soil, leaf, and fruit nutrient concentrations and cash costs and returns as a randomized complete block design with two treatments replicated eight times. Regression analysis of soil $\mathrm{NO}_{3}{ }^{-}, \mathrm{P}$, and $\mathrm{K}$ contents and leaf $\mathrm{N}, \mathrm{P}$, and $\mathrm{K}$ concentrations against time since experiment establishment was conducted, respectively, using the REG procedure. Probability levels less than 0.05 were designated as significant.

\section{Results and Discussion}

Polypropylene groundcover effects on soil nutrient availability. Initial soil fertility was uniform among the 16 plots in this study in 2000 before the treatments were first imposed in April 2001 (Figs. 1 and 2). Soil $\mathrm{NO}_{3}{ }^{-}$content was statistically similar in the cover and no cover treatments each year in August except 2005, when soil under polypropylene cover had a $30.3 \%$ reduction in $\mathrm{NO}_{3}{ }^{-}$compared with the noncovered soil (Fig. 1). Difference in soil available $\mathrm{P}$ was not significant between the cover and no cover treatments regardless of year (data not presented). Like $\mathrm{NO}_{3}^{-}$, soil under polypropylene cover had similar soil available $\mathrm{K}$ content as the noncovered soil each year except 2005, when soil available $\mathrm{K}$ was $13.6 \%$ lower in the covered soil relative to the noncovered soil (Fig. 2). No significant

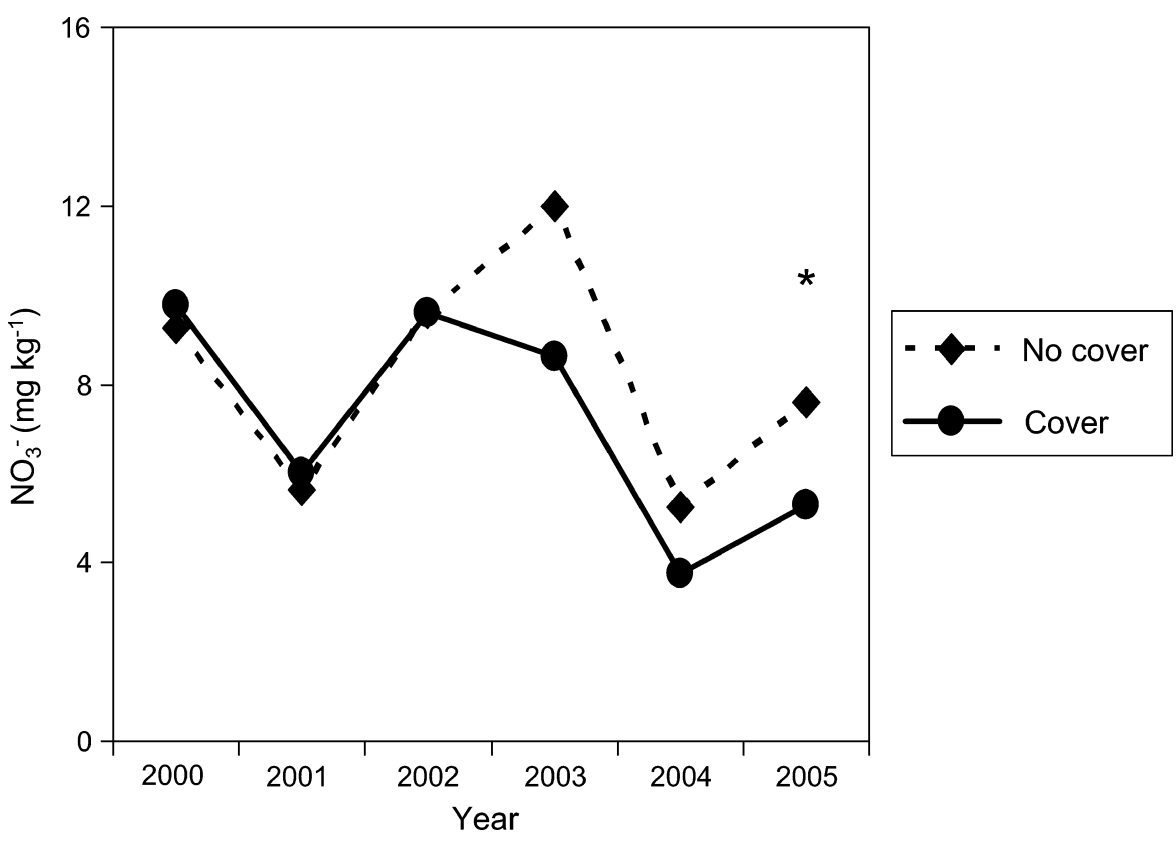

Fig. 1. Polypropylene groundcover effects on Mehlich III extracted soil nitrate content. *The treatment effect is significant at $P=0.05$. effects of polypropylene cover on soil available $\mathrm{Ca}, \mathrm{Mg}, \mathrm{S}, \mathrm{B}, \mathrm{Zn}, \mathrm{Mn}$, and $\mathrm{Cu}, \mathrm{pH}$, or organic matter were observed in any of the 5 years after treatment initiation (data not presented).

Although polypropylene cover serves as a physical barrier to prevent organic matter additions to the soil, no significant difference in soil organic matter was observed between the two treatments after 5-year experimentation (data not presented). This trend may be attributed to the assumption that although tree leaves fall on the top of polypropylene cover in the groundcovered treatment, they could still be decomposed by soil microbes and washed down through the polypropylene cover and then down to the soil by rain and irrigation water.

Overall, plots under different treatments had similar available elemental nutrient levels in the soil during the first four years (2001 to 2004) of experimentation; after that, plots under polypropylene cover had lower soil $\mathrm{N}$ and $\mathrm{K}$ levels. This trend was within our expectation because tree growth (such as trunk cross-sectional area, and so on) and fruit yield were significantly enhanced by over $30 \%$ with polypropylene cover compared with no cover during the 5-year period (Núñez-Elisea et al., 2004, 2005a, 2005b). Enhanced tree growth and fruit yield with polypropylene cover increased the removal of nutrients from the soil, thus reducing available soil nutrient contents. Meanwhile, our results suggest that increased soil moisture content and soil temperature (data not presented) were both likely attributed to the greater tree growth and fruit yield with the covered trees than noncovered trees.

When soil $\mathrm{NO}_{3}{ }^{-}, \mathrm{P}$, and $\mathrm{K}$ contents were linearly regressed against time since experiment establishment, there was no significant 


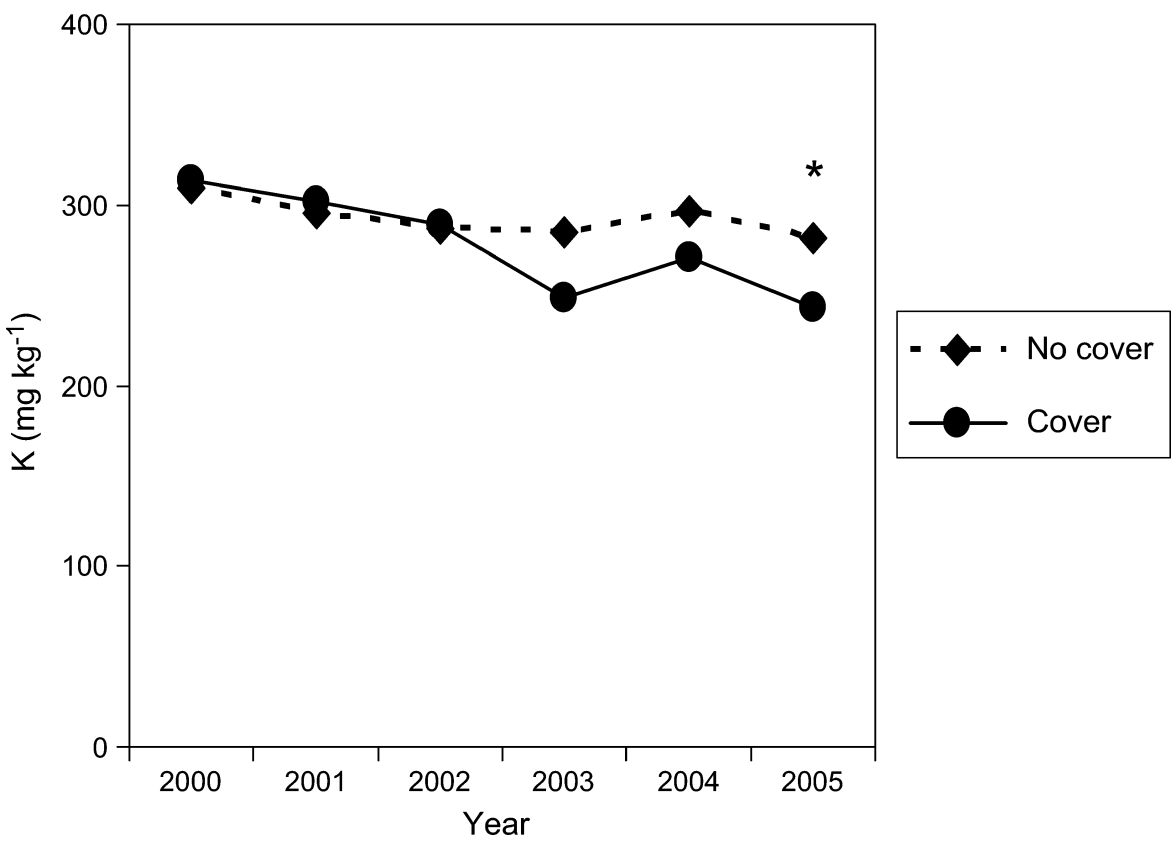

Fig. 2. Polypropylene groundcover effects on Mehlich III extracted soil potassium content.

*The treatment effect is significant at $P=0.05$.

relationship between soil $\mathrm{N}$ or $\mathrm{P}$ content and time for either treatment (data not presented). This suggest soil $\mathrm{NO}_{3}{ }^{-}$and $\mathrm{P}$ were stable in both treatments during the 5 years of experimentation. On the other hand, there was soil $\mathrm{K}$ and time in the polypropylene cover treatment. No significant association between soil $\mathrm{K}$ and time was observed in the noncovered treatment.

Polypropylene groundcover effects on leaf and fruit nutrition. Polypropylene cover exerted a consistent effect on leaf $\mathrm{N}$ concentration each year except 2001, the first year of experimentation (Fig. 3). Leaf $\mathrm{N}$ concentraa significant negative relationship between

tions in August after fruit harvest were $16.1 \%, 13.2 \%, 10.6 \%$, and $19.3 \%$ greater with the covered trees than noncovered trees in 2002 to 2005, respectively. Because tree size and fruit yield was over $30 \%$ greater in the cover than no cover treatments (data not presented), this suggests that the total amount of $\mathrm{N}$ uptake per tree has been substantially enhanced as a result of polypropylene cover. Our results are different from those in western Canada (Neilsen et al., 2003) in that no significant differences in leaf $\mathrm{N}$ concentration were observed on apple trees between inrow black polypropylene cover and herbicide application in any of the 6 years from 1994 to

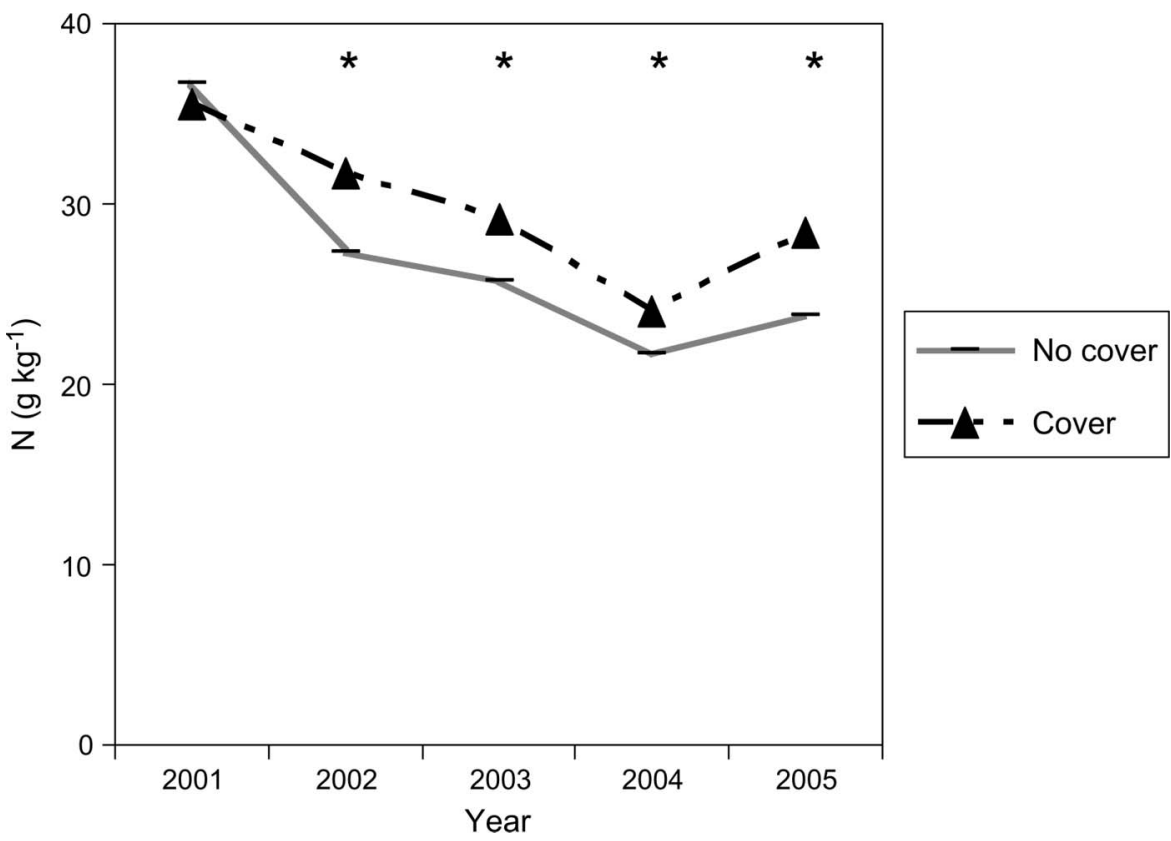

Fig. 3. Polypropylene groundcover effects on leaf nitrogen concentration of Regina on Gisela 6. *The treatment effect is significant at $P=0.05$.
1999. Insignificant differences observed in the study of Neilsen et al. (2003) were likely because $\mathrm{N}$ was fertigated, which probably negated the fabric groundcover effect on leaf $\mathrm{N}$ relative to the control.

On the other hand, leaf $\mathrm{P}$ concentration in August after fruit harvest was $36.2 \%, 36.5 \%$, $21.1 \%$, and $18.6 \%$ lower with the covered trees than the noncovered trees in 2002, 2003, 2004, and 2005, respectively (Fig. 4). However, leaf P level was identical for the two treatments in 2001, the first year of experimentation. Unlike $\mathrm{N}$ and $\mathrm{P}$, leaf $\mathrm{K}$ concentrations in August were almost identical for the two treatments in all the five seasons (not presented). Our results generally contrast with those of Neilsen et al. (2003) on leaf $\mathrm{P}$ concentrations but are consistent for leaf $\mathrm{K}$ concentrations

Similar to leaf $\mathrm{P}$, leaf Ca concentrations in August were reduced by $12.9 \%, 11.2 \%$, and $9.2 \%$ in 2002,2003 , and 2005 , respectively, in the polypropylene cover plots (Table 1). Leaf $\mathrm{Mg}$ concentration was lowered by $24.4 \%, 12.5 \%$, and $6.3 \%$ in 2002,2003 , and 2004 , respectively, with polypropylene cover (Table 1). The reduced leaf $\mathrm{P}, \mathrm{Ca}$, and $\mathrm{Mg}$ concentrations with the covered trees were attributed to the diluting effects of enhanced tree growth and fruit yield. Neilsen et al. (2003) also reported lower leaf $\mathrm{Ca}$ and $\mathrm{Mg}$ concentrations with fabric groundcovered apple trees in 2 of 6 years in their study.

The effects of polypropylene groundcover on leaf $\mathrm{S}, \mathrm{B}$, and $\mathrm{Mn}$ concentrations in August after fruit harvest were statistically insignificant each year (Table 1). However, a significant increase in leaf $\mathrm{Zn}$ concentration was observed in 2004, and a significant increment in $\mathrm{Cu}$ concentration was detected in 2002, 2004, and 2005.

Overall, our results suggest that leaf nutrient concentrations respond differentially to in-row polypropylene groundcover, and the responses vary with growing season. The total uptake of N, P, K, Ca, Mg, B, Zn, Mn, or $\mathrm{Cu}$ per tree per year seems to be significantly increased with polypropylene cover relative to no cover because of an over $30 \%$ increase in both tree growth and fruit yield in the polypropylene-covered treatment (NúñezElisea et al., 2004, 2005a, 2005b). The enhanced uptake of nutrients from soil with polypropylene cover may be attributable to the larger soil volume penetrated by root systems of groundcovered trees, increased soil moisture supply, elevated soil temperature beneath the polypropylene cover, and/or reduced competition from other plants such as weeds in the covered treatment (NúñezElisea et al., 2005b). Our results indicate that the availability of $\mathrm{P}, \mathrm{Ca}$, and $\mathrm{Mg}$ nutrients in soil generally remains unchanged with polypropylene groundcover. From a long-term perspective, more fertilizers may need to be applied on polypropylene-covered sweet cherry trees because of the enhanced tree growth and fruit production.

Similar to leaf nutrient concentrations, the responses of nutrient concentrations in mature fruit to polypropylene groundcover 


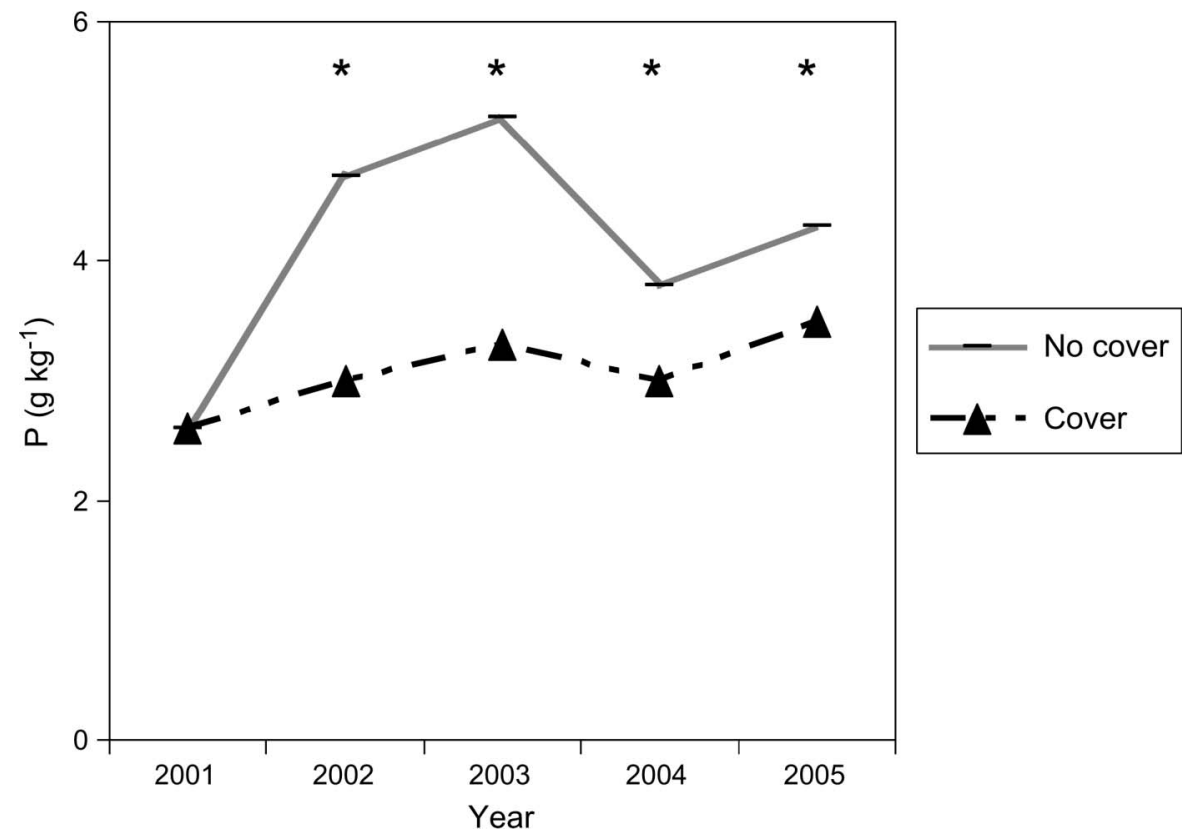

Fig. 4. Polypropylene groundcover effects on leaf phosphorus concentration of Regina on Gisela 6. *The treatment effect is significant at $P=0.05$.

Table 1. Polypropylene groundcover effects on leaf $\mathrm{Ca}, \mathrm{Mg}, \mathrm{S}, \mathrm{B}, \mathrm{Zn}, \mathrm{Mn}$, and $\mathrm{Cu}$ concentrations.

\begin{tabular}{|c|c|c|c|c|c|c|c|c|}
\hline $\mathrm{Yr}$ & Treatment & $\begin{array}{c}\mathrm{Ca} \\
\mathrm{g} \cdot \mathrm{kg}^{-1}\end{array}$ & $\begin{array}{c}\mathrm{Mg} \\
\mathrm{g} \cdot \mathrm{kg}^{-1}\end{array}$ & $\begin{array}{c}\mathrm{S} \\
\mathrm{g} \cdot \mathrm{kg}^{-1}\end{array}$ & $\begin{array}{c}\text { B } \\
\mu \mathrm{g} \cdot \mathrm{g}^{-1}\end{array}$ & $\begin{array}{c}\mathrm{Zn} \\
\mu \mathrm{g} \cdot \mathrm{g}^{-1}\end{array}$ & $\begin{array}{c}\mathrm{Mn} \\
\mu \mathrm{g} \cdot \mathrm{g}^{-1}\end{array}$ & $\begin{array}{c}\mathrm{Cu} \\
\mu \mathrm{g} \cdot \mathrm{g}^{-1}\end{array}$ \\
\hline \multirow[t]{2}{*}{2001} & No cover & $9.5 \mathrm{a}^{\mathrm{z}}$ & $2.4 \mathrm{a}$ & $0.5 \mathrm{a}$ & $35.6 \mathrm{a}$ & $22.8 \mathrm{a}$ & $48.9 \mathrm{a}$ & $14.3 \mathrm{a}$ \\
\hline & Cover & $9.6 \mathrm{a}$ & $2.6 \mathrm{a}$ & $0.5 \mathrm{a}$ & $35.9 \mathrm{a}$ & $25.6 \mathrm{a}$ & $64.0 \mathrm{a}$ & $13.6 \mathrm{a}$ \\
\hline \multirow[t]{2}{*}{2002} & No cover & $15.5 \mathrm{a}$ & $4.1 \mathrm{a}$ & $1.9 \mathrm{a}$ & $52.4 \mathrm{a}$ & $24.3 \mathrm{a}$ & $92.4 \mathrm{a}$ & $9.1 \mathrm{~b}$ \\
\hline & Cover & $13.5 \mathrm{~b}$ & $3.1 \mathrm{~b}$ & $1.8 \mathrm{a}$ & $50.5 \mathrm{a}$ & $20.0 \mathrm{a}$ & $88.9 \mathrm{a}$ & $10.4 \mathrm{a}$ \\
\hline \multirow[t]{2}{*}{2003} & No cover & $13.4 \mathrm{a}$ & $3.2 \mathrm{a}$ & $0.9 \mathrm{a}$ & $52.4 \mathrm{a}$ & $12.8 \mathrm{a}$ & $57.4 \mathrm{a}$ & $8.4 \mathrm{a}$ \\
\hline & Cover & $11.9 \mathrm{~b}$ & $2.8 \mathrm{~b}$ & $1.0 \mathrm{a}$ & $48.6 \mathrm{a}$ & $13.0 \mathrm{a}$ & $55.1 \mathrm{a}$ & $8.6 \mathrm{a}$ \\
\hline \multirow[t]{2}{*}{2004} & No cover & $13.8 \mathrm{a}$ & $3.2 \mathrm{a}$ & $1.3 \mathrm{a}$ & $78.8 \mathrm{a}$ & $10.4 \mathrm{~b}$ & $50.3 \mathrm{a}$ & $4.0 \mathrm{~b}$ \\
\hline & Cover & $13.5 \mathrm{a}$ & $3.0 \mathrm{~b}$ & $1.3 \mathrm{a}$ & $77.8 \mathrm{a}$ & $12.7 \mathrm{a}$ & $50.9 \mathrm{a}$ & $4.4 \mathrm{a}$ \\
\hline \multirow[t]{2}{*}{2005} & No cover & $15.3 \mathrm{a}$ & $3.9 \mathrm{a}$ & $1.4 \mathrm{a}$ & $70.9 \mathrm{a}$ & $12.9 \mathrm{a}$ & $43.1 \mathrm{a}$ & $5.9 \mathrm{~b}$ \\
\hline & Cover & $13.9 \mathrm{~b}$ & $3.7 \mathrm{a}$ & $1.5 \mathrm{a}$ & $68.1 \mathrm{a}$ & $14.8 \mathrm{a}$ & $45.1 \mathrm{a}$ & $6.4 \mathrm{a}$ \\
\hline
\end{tabular}

${ }^{\mathrm{z}}$ Values in column within each year followed by the same letter are not significantly different at $5 \%$ probability level.

were nutrient-specific in 2005 , the only year these analyses were made (Table 2). Fruit N concentration was $18.8 \%$ greater in the covered plots than noncovered plots. However, fruit $\mathrm{P}$ concentration was lowered by $8.3 \%$ because of polypropylene cover. Similar to $\mathrm{N}$, fruit $\mathrm{S}$ concentration was increased by $33.3 \%$ with polypropylene cover relative to no cover. No significant difference was observed in fruit $\mathrm{K}, \mathrm{Ca}, \mathrm{Mg}, \mathrm{B}, \mathrm{Zn}, \mathrm{Mn}$, or $\mathrm{Cu}$ concentration between the covered and noncovered trees.

When leaf $\mathrm{N}, \mathrm{P}$, and $\mathrm{K}$ concentrations were linearly regressed against time, respectively, there was a nearly significant negative relationship $(P<0.10)$ between leaf $\mathrm{N}$ and time for both treatments (data not presented). pared for tree planting by ripping, disking, root removal, and fumigation (Table 3). However, the polypropylene cover treatment resulted in an increase of $36.0 \%, 7.1 \%$, $17.1 \%, 56.5 \%$, and $14.3 \%$ in annual cash costs compared with no cover in 2001, 2002, 2003, 2004, and 2005, respectively. Higher annual cash costs with polypropylene cover in 2001 were primarily the result of the purchasing and installation of polypropylene cover. However, labor costs for pruning the bigger trees and harvesting the higher fruit yields and an interest charge for previous year's establishment costs were the main reasons for increased annual cash costs with the polypropylene cover treatment in subsequent years.

Harvesting fruit began in 2004. Gross returns from fruit sales were $218.3 \%$ and $43.1 \%$ greater with the polypropylene-covered trees than noncovered trees in 2004 and 2005, respectively (Table 3 ). Fruit yield was substantially higher with the covered trees than noncovered trees in both 2004 and 2005 (Núñez-Elisea et al., 2004, 2005a, 2005b), which resulted in significantly greater returns for the polypropylene cover treatment.

Cumulative cash costs for orchard establishment were identical for the polypropylene cover and no cover treatments in 2000 (Fig. 5). From 2001 through 2003, however, the polypropylene cover treatment bore significantly higher cumulative cash costs. In this trial, the costs to establish an orchard with polypropylene cover increased by $\$ 5246.44$ $\mathrm{ha}^{-1}$ within the first 4 years before fruit production. However, in the fifth year-the first harvest year-net returns were much greater for the polypropylene cover treatment, lowering cumulative cash costs with polypropylene cover to almost equal that of no cover. The second crop year, with returns that exceeded no cover by $\$ 4030.03 \mathrm{ha}^{-1}$, resulted in significantly lower cumulative cash costs with polypropylene cover. The increased financial risk to purchase and install polypropylene cover was greatly reduced by the increases in sweet cherry returns in this treatment. be attributed to the fact that no $\mathrm{N}$ fertilizer was applied from 2001 to 2003 and N application rate was very low in 2004 and 2005 in both treatments. A close to significant positive relationship $(P<0.10)$ was observed between leaf $\mathrm{P}$ and time in the polypropylenecovered treatment. No significant association was observed between leaf $\mathrm{P}$ and time in the noncovered treatment or between leaf $\mathrm{K}$ and time in either treatment.

Polypropylene groundcover effects on cash costs and returns. Annual cash costs were identical for the cover and no cover treatments in 2000 , when the field was pre-

Table 2. Polypropylene groundcover effects on fruit N, P, K, Ca, Mg, S, B, Zn, Mn, and Cu concentrations in 2005 .

\begin{tabular}{lcccccccccc}
\hline & $\mathrm{N}$ & $\mathrm{P}$ & $\mathrm{K}$ & $\mathrm{Ca}$ & $\mathrm{Mg}$ & $\mathrm{S}$ & $\mathrm{B}$ & $\mathrm{Zn}$ & $\mathrm{Mn}$ \\
$\mathrm{Treatment}$ & $\mathrm{g} \cdot \mathrm{kg}^{-1}$ & $\mathrm{~g} \cdot \mathrm{kg}^{-1}$ & $\mathrm{~g} \cdot \mathrm{kg}^{-1}$ & $\mathrm{~g} \cdot \mathrm{kg}^{-1}$ & $\mathrm{~g} \cdot \mathrm{kg}^{-1}$ & $\mathrm{~g} \cdot \mathrm{kg}^{-1}$ & $\begin{array}{c}\mathrm{Cu} \cdot \mathrm{g}^{-1} \\
\mu \mathrm{g} \cdot \mathrm{g}^{-1}\end{array}$ & $\begin{array}{c}\mu \mathrm{g}^{-1} \\
\mu \mathrm{g} \cdot \mathrm{g}^{-1}\end{array}$ \\
\hline No cover & $6.9 \mathrm{~b}^{\mathrm{z}}$ & $1.2 \mathrm{a}$ & $10.3 \mathrm{a}$ & $0.9 \mathrm{a}$ & $0.6 \mathrm{a}$ & $0.3 \mathrm{~b}$ & $38.1 \mathrm{a}$ & $2.6 \mathrm{a}$ & $1.0 \mathrm{a}$ & $3.9 \mathrm{a}$ \\
Cover & $8.2 \mathrm{a}$ & $1.1 \mathrm{~b}$ & $11.6 \mathrm{a}$ & $1.0 \mathrm{a}$ & $0.6 \mathrm{a}$ & $0.4 \mathrm{a}$ & $40.0 \mathrm{a}$ & $3.3 \mathrm{a}$ & $1.0 \mathrm{a}$ & $3.9 \mathrm{a}$ \\
\hline
\end{tabular}

${ }^{z}$ Values in column followed by the same letter are not significantly different at $5 \%$ probability level.

Table 3. Polypropylene groundcover effects on annual cash costs and gross returns. ${ }^{\mathrm{z}}$

\begin{tabular}{|c|c|c|c|}
\hline Yr & Treatment & $\begin{array}{c}\text { Annual } \\
\text { cash costs } \\
\left(\$ \mathrm{ha}^{-1}\right)\end{array}$ & $\begin{array}{l}\text { Gross } \\
\text { returns } \\
\left(\$ \mathrm{ha}^{-1}\right)\end{array}$ \\
\hline 2000 & $\begin{array}{l}\text { No cover } \\
\text { Cover }\end{array}$ & $\begin{array}{l}2456.08 \mathrm{a} \\
2456.08 \mathrm{a}\end{array}$ & \\
\hline 2001 & $\begin{array}{l}\text { No cover } \\
\text { Cover }\end{array}$ & $\begin{array}{l}12,185.73 \mathrm{~b} \\
16,569.80 \mathrm{a}\end{array}$ & \\
\hline 2002 & $\begin{array}{l}\text { No cover } \\
\text { Cover }\end{array}$ & $\begin{array}{l}5423.46 \mathrm{~b} \\
5807.57 \mathrm{a}\end{array}$ & \\
\hline 2003 & $\begin{array}{l}\text { No cover } \\
\text { Cover }\end{array}$ & $\begin{array}{l}2794.85 \mathrm{~b} \\
3273.11 \mathrm{a}\end{array}$ & \\
\hline 2004 & $\begin{array}{l}\text { No cover } \\
\text { Cover }\end{array}$ & $\begin{array}{l}4379.09 \mathrm{~b} \\
6854.76 \mathrm{a}\end{array}$ & $\begin{array}{r}3743.90 \mathrm{~b} \\
11917.70 \mathrm{a}\end{array}$ \\
\hline 2005 & $\begin{array}{l}\text { No cover } \\
\text { Cover }\end{array}$ & $\begin{array}{l}4187.29 \mathrm{~b} \\
4785.11 \mathrm{a}\end{array}$ & $\begin{array}{r}9359.99 \mathrm{~b} \\
13390.02 \mathrm{a}\end{array}$ \\
\hline
\end{tabular}

${ }^{\mathrm{z}}$ Values in column within each year followed by the same letter are not significantly different at $5 \%$ probability level. 


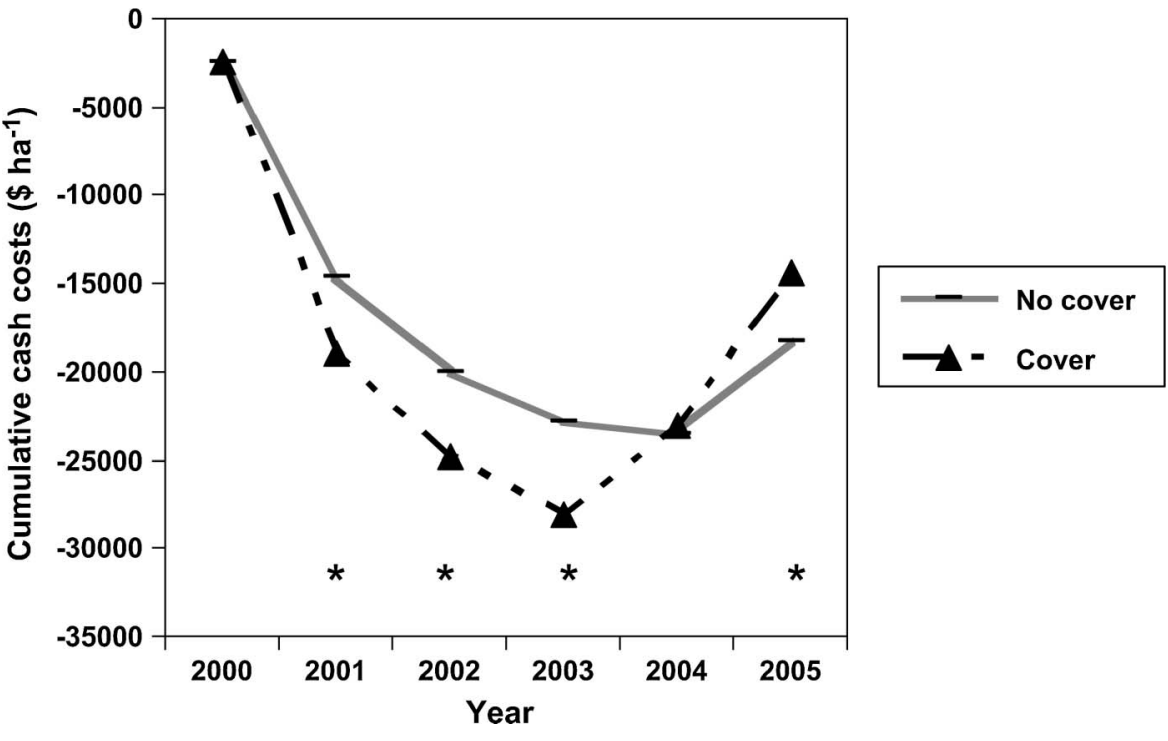

Fig. 5. Polypropylene groundcover effects on cumulative cash costs.

*The treatment effect is significant at $P=0.05$.

Although the results of this 5-year study demonstrated that polypropylene groundcover in the row area of young sweet cherry trees generally exerts no adverse effect on soil nutrient availability or mineral nutrition of leaf and fruit, integration of polypropylene groundcover into a tree fruit production system requires knowledge and consideration of tree physiology, soil and climate type, grower preferences and resources, and local regulations concerning water and soil quality. For instance, long-term use of polypropylene groundcover may be more profitable on orchards with higher soil organic matter content because polypropylene cover may reduce soil organic matter as a result of its prevention of organic matter additions to the soil. Overall, biologic, economic, and environmental factors should all be considered in adopting polypropylene cover as an in-row ground management alternative for orchards.

\section{Conclusions}

Soil available $\mathrm{NO}_{3}^{-}, \mathrm{P}, \mathrm{K}, \mathrm{Ca}, \mathrm{Mg}, \mathrm{S}, \mathrm{B}$, $\mathrm{Zn}, \mathrm{Mn}$, and $\mathrm{Cu}$ contents did not differ significantly between the polypropylene groundcover and no cover treatments any year except the last year (2005), when soil $\mathrm{N}$ and $\mathrm{K}$ levels were lower under the cover treatment. Leaf $\mathrm{N}$ concentration was enhanced by $11 \%$ to $19 \%$ each year with polypropylene cover compared with no cover. However, leaf $\mathrm{P}$ concentration was lowered by $19 \%$ to $37 \%$ in the polypropylene cover treatment each year; and leaf $\mathrm{Ca}$ and $\mathrm{Mg}$ concentrations were reduced by $9 \%$ to $13 \%$ and $6 \%$ to $24 \%$, respectively, with polypro-
Elmore, C.L., I. Merwin, and D. Cudney. 1997. Weed management in tree fruit, nuts, citrus and vine crops, p. 17-29. In: M.E. McGiffen (ed.). Weed management in horticultural crops. ASHS Press, Alexandria, Va.

Gavlak, R.G., D.A. Horneck, and R.O. Miller. 1994. Plant, soil and water reference methods for the western region. W. Reg. Ext. Publ.125. University of Alaska, Fairbanks, Alaska.

Geldart, H.G. 1994. The impact of replant problems on the economics of high density apple plantings. Acta Hort. 363:11-18.

Glover, J.D., J.P. Reganold, and P.K. Andrews. 1999. Systematic method for rating soil quality of conventional, organic, and integrated apple orchards in Washington state. Agr. Ecosyst. Environ. 80:29-45.

Johnson, D.S. and T.J. Samuelson. 1990. Shortterm effects of changes in soil management and nitrogen fertilizer application on 'Bramley's Seedling' apple trees: II. Effects on mineral composition and storage quality of fruit. $\mathrm{J}$. Hort. Sci. 65:495-502.

Mäge, F. 1982. Black plastic mulching, compared to other orchard soil management methods. Sci. Hort. (Amsterdam) 16:131-136.

Mehlich, A. 1984. Mehlich 3 soil test extractant: A modification of Mehlich 2. Commun. Soil Sci. Plant Anal. 15:1409-1416.

pylene cover in 3 of 5 years. Reduced leaf $P$, $\mathrm{Ca}$, and $\mathrm{Mg}$ concentrations were attributed to the tissue diluting effects resulting from enhanced tree growth and fruit production. The total uptake of $\mathrm{N}, \mathrm{P}, \mathrm{K}, \mathrm{Ca}, \mathrm{Mg}, \mathrm{B}, \mathrm{Zn}$, $\mathrm{Mn}$, and $\mathrm{Cu}$ nutrients by trees seemed to be significantly increased with polypropylene cover relative to no cover during the 5-year period. The enhanced uptake of most nutrients from soil with the polypropylene cover treatment may be the result of the larger soil volume penetrated by root systems of groundcovered trees. From a long-term perspective, more fertilizers may need to be applied on polypropylene groundcovered sweet cherry trees because of this enhanced tree growth and fruit production. Cumulative cash costs for the first 4 years before fruit production were $\$ 5246 /$ ha higher with polypropylene cover relative to no cover; however, these costs were offset quickly by the increased returns from enhanced fruit yields. In conclusion, biologic, economic, and environmental factors should all be considered in adopting polypropylene cover as an in-row ground management alternative for orchards.

\section{Literature Cited}

Combs, S.M. and M.V. Nathan. 1998. Soil organic matter, p. 53-58. In: J.R. Brown (ed.). Recommended chemical soil test procedures for the north central region. NCR Research Publication No. 221. University of Missouri, Columbia, Mo.

Derr, J.F. 2001. Biological assessment of herbicide use in apple production. II. Estimated impacts following loss of specific herbicides. HortTechnology 111:20-25.
Merwin, I.A., J.A. Ray, T.S. Steenhuis, and J. Boll. 1996. Ground cover management systems influence fungicide and nitrate-N concentrations in leachate and runoff from a New York apple orchard. J. Amer. Soc. Hort. Sci. 21:249-257.

Neilsen, G.H., E.J. Hogue, T. Forge, and D. Neilsen. 2003. Mulches and biosolids affect vigor, yield, and leaf nutrition of fertigated high density apple. HortScience 38:41-45.

Núñez-Elisea, R., H. Cahn, L. Caldeira, and C. Seavert. 2004. Effect of a synthetic fabric row cover on soil moisture content, growth and fruiting of young sweet cherry trees (Prunus avium L. cv. 'Regina'/Gisela 6). HortScience 39:850 (abstr.).

Núñez-Elisea, R., H. Cahn, L. Caldeira, and C. Seavert. 2005a. Synthetic fabric covers as a tool to promote early yields and fruit quality in 'Regina' sweet cherry. Compact Fruit Tree 38:38-39.

Núñez-Elisea, R., H. Cahn, L. Caldeira, and C. Seavert. 2005b. Polypropylene row covers greatly enhance growth and production of fourth-leaf sweet cherry trees. HortScience 40:1129 (abstr.).

Parker, M.L. and J Hull. 1993. Orchard floor management affects cherry tree growth and moisture utilization. Acta Hort. 343:201-213.

SAS Institute. 2002. The SAS System for Microsoft Windows. Release 8.2. Cary, N.C.

Shribbs, J.M. and W.A. Skroch. 1986. Influence of 12 ground cover systems on young 'Smoothee Golden Delicious' apple trees: I. Growth. J. Amer. Soc. Hort. Sci. 111:525-528.

Stevenson, D.S. and G.H. Neilsen. 1990. Nitrogen additions and losses to drainage in orchard type irrigated lysimeters. Can. J. Soil Sci. 70:11-19.

Watson, M.E. and J.R. Brown. 1998. pH and lime requirement, p. 13-16. In: J.R. Brown (ed.). Recommended chemical soil test procedures for the north central region. NCR Research Publication No. 221. University of Missouri, Columbia, Mo. 